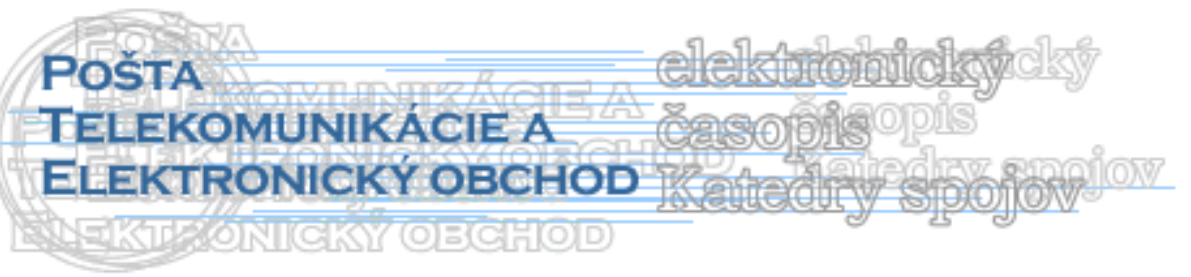

\title{
ANALÝZA VPLYVU VYBRANÝCH FAKTOROV NA VÝŠKU MZDY ZAMESTNANCOV V ŽILINSKOM KRAJI
}

\author{
Lucia Švábová*
}

\section{Úvod}

Byt' zamestnaný je väčšinou l'udí brané ako samozrejmost'. Mnohí z nich si však ani neuvedomujú, že sú vlastne v nevýhodnom postavení. Predávajú to najcennejšie, čo majú, a to svoj čas a často zato dostávajú neadekvátne finančné ohodnotenie. L'udia s nižším vzdelaním majú aj menšiu možnost' výberu zamestnania. Bez práce sa časom ocitnú v zlej finančnej situácii, a preto sa nutne musia zamestnat', aby prežili. Človeku, ktorý chodí do práce, ostane už málo energie a vol'ného času, aby si zvýšil kvalifikáciu a znalosti. Navyše, mnoho l'ud’om zarobené peniaze nepostačujú na pokrytie životných nákladov, a tak si berú pôžičky, aby pokryli chýbajúce prostriedky v rodinnom rozpočte. A tak keby sa aj chceli stat' podnikatel'mi, už nemôžu, nemajú na to ani finančné prostriedky a ani znalosti. Zamestnanci sú samozrejme potrební. Potrebujú ich podnikatelia, firmy aj štát a dokážu si ich kúpit'. Tu sa však stretávame s problémom - za kol'ko? Zamestnanci nevedia odhadnút' svoju cenu na trhu práce, a preto často pracujú pod cenu, za ktorú by mohli robit'. Ďalším problémom je ponuka práce. Medzi jednotlivými regiónmi sú ekonomické, a teda aj sociálne rozdiely. Tieto vždy boli, sú, a aj budú. Vznikli historickým vývojom v dôsledku rozdielnych geografických a prírodných podmienok. Je akceptovatel'né, že región s krajským mestom, ktoré je zároveň hlavným mestom Slovenska, teda Bratislavský región, je ekonomicky a sociálne najvyspelejší, pretože sa v ňom sústred’uje zákonodarná a výkonná moc, kultúrny a hospodársky život, na rozdiel od ostatných regiónov Slovenska.

Ciel’om príspevku bude na základe teoretických poznatkov a získaných údajov od spoločnosti Trexima, a.s. porovnat' hrubé priemerné mesačné mzdy zamestnancov v Žilinskom kraji na základe rôznych faktorov a charakterizovat' príčiny rozdielov.

\section{Odmeňovanie zamestnancov}

Ciel'om každého zamestnávatel'a je mat' lojálnych a spokojných zamestnancov, ktorí prinášajú výkon a starajú o svoj pracovný rast. Svojou prácou prispievajú k plneniu ciel'ov a vízií spoločnosti. K prioritám zamestnávatel'ov $v$ súčasnosti patrí aj spokojnost' zamestnancov a ich motivácia k zvyšovaniu produktivity práce. Motivácia je hlavným faktorom, vplývajúcim na pracovný výkon zamestnanca. Je to hnacia sila, prostredníctvom ktorej l’udia dosahujú svoje ciele, napíňajú svoje potreby, či udržujú svoje hodnoty. Riadenie pracovného výkonu využiva rôzne teórie motivácie. Vychádza z poznatkov, že l'udské

\footnotetext{
* RNDr. Lucia Švábová, Katedra kvantitatívnych metód a hospodárskej informatiky, Fakulta prevádzky a ekonomiky dopravy a spojov, Žilinská univerzita tel.: +421 415133255

e-mail: lucia.svabova@fpedas.uniza.sk
} 
správanie je cielené, podmienené a motivované. Príčinou správania sa človeka je motív, to znamená snaha uspokojit' svoju potrebu. Hodnotenie zamestnancov je súčast’ou ich motivácie, preto musí byt' nastavené tak, aby skutočne bolo motivačné. Správne nastavenie procesu hodnotenia, ktorý je aj určitým stimulom pre zvýšenie pracovného výkonu, je dôležitou činnost'ou, ktorá podmieňuje efektívnu organizáciu a fungovanie celej firmy. Hodnotenie vychádza z ciel'ov a vízie firmy. Zameriava sa na riadenie výkonnosti zamestnanca a na zist'ovanie jeho rozvojových potrieb. Správne zavedený systém hodnotenia podporuje iniciatívu zamestnancov, stimuluje ich spätnú väzbu a snaží sa dat' správneho človeka na správne miesto pri optimálnom využití jeho schopností. Hodnotenie zamestnancov slúži ako podklad pre viacero úkonov. Najdôležitejším je odmeňovanie. To záleží od plnenia daných ciel'ov, vyjadrených kritériami. Preto ak majú byt' zamestnanci, odmeňovaní podl'a kritérií, objektívne a pozitívne motivovaní, je jeho spojitost' s hodnotením nevyhnutná. Odmeňovanie zahŕňa všetky formy ohodnotenia práce, čiže finančné aj nefinančné. Hlavným ciel'om je nájst' ideálny pomer medzi množstvom odvedenej práce, nákladmi na zamestnancov a zamestnaneckej spokojnosti. [13]

\section{Regióny Slovenska}

Ciel'om tohto príspevku je poukázat' na diferenciáciu miezd zamestnancov vo vybranom kraji Slovenska, nezaobídeme sa teda bez definovania objektu výskumu. Budeme porovnávat' mzdy zamestnancov podl'a jednotlivých samosprávnych krajov. Teda ako observačné jednotky sme použili kraje, ktoré sú na regionálnej úrovni NUTS 3: Bratislavský, Trnavský, Nitriansky, Trenčiansky, Žilinský, Banskobystrický, Košický a Prešovský kraj. Pre potreby tohto príspevku sme si zvolili Žilinský kraj, v ktorom sa zameriame na zistenie rozdielov medzi mzdami zamestnancov v závislosti od rôznych faktorov a porovnáme výšku mzdy zamestnancov tohto kraja s priemernou výškou mzdy na Slovensku. [12]

\subsection{Slovensko}

Podl'a Štatistického úradu Slovenskej republiky malo k 31. 12. 2011 Slovensko 5,4 milióna obyvatel'ov z toho bolo 51,4\% žien. V roku 2011 bolo v priemere 2351,4 tisíc pracujúcich, čo predstavovalo $86,5 \%$ podiel pracujúcich z ekonomicky aktívneho obyvatel'stva. Najviac zamestnaných bolo vodvetví priemyslu (635 tisíc) a najmenej v činnosti extrateritoriálnych organizácií (1 tisíc). Priemerná mesačná mzda za rok 2011 bola $786 €$, pričom najvyššiu nominálnu mesačnú mzdu mali zamestnanci v informačných a komunikačných činnostiach (1 692€) a najnižšiu mali zamestnanci v stravovacích a ubytovacích službách (563€) [11].

\section{2. Žilinský kraj}

Žilinský kraj tvorí 13,9\% rozlohy štátu a s rozlohou $6809 \mathrm{~km}^{2}$ je tretím najväčším krajom. K 31.12.2010 mal 698274 obyvatel'ov, čo predstavuje podiel 12,8\% na celkovom počte obyvatel'ov. Žilinský kraj sa zarad'uje medzi významné hospodárske regióny s rozvinutým priemyslom. V roku 2010 bolo v kraji 47,8\% ekonomicky aktívnych obyvatel'ov.

Dostupné údaje o priemerných mesačných mzdách podla kritérií vzdelania a veku sú spracované v nasledujúcej tabul'ke. [13] 
Tabul'ka 1: Priemerná mesačná mzda zamestnancov v Žilinskom kraji za rok 2010 podla Štatistického úradu SR

\begin{tabular}{|l|r|l|r|}
\hline \multicolumn{4}{|c|}{ Priemerná mesačná mzda v Žilinskom kraji v $€$} \\
\hline Podl'a vzdelania & & Podl'a veku \\
\hline Základné & 510 & do 19 rokov & 430 \\
\hline Učňovské & 602 & od 20 do 24 rokov & 563 \\
\hline stredné bez maturity & 600 & od 25 do 29 rokov & 709 \\
\hline učňovské s maturitou & 731 & od 30 do 34 rokov & 801 \\
\hline uplné stredné všeobecné & 728 & od 35 do 39 rokov & 799 \\
\hline úplné stredné odborné & 739 & od 40 do 44 rokov & 783 \\
\hline vyššie odborné & 798 & od 45 do 49 rokov & 760 \\
\hline vysokoškolské 1. stupeň & 793 & od 50 do 54 rokov & 748 \\
\hline vysokoškolské 2. stupeň & 1079 & od 55 do 59 rokov & 746 \\
\hline vysokoškolské 3. stupeň & 1191 & nad 60 rokov & 758 \\
\hline
\end{tabular}

Zdroj: Vlastné spracovanie údajov zo Štatistického úradu SR

V štruktúre evidovaných zamestnancov za rok 2010 v závislosti od stupňa dosiahnutého vzdelania dosahujú najvyššiu mzdu zamestnanci s vysokoškolským vzdelaním 3. stupňa, a to priemerne 1191€. Naopak, najnižšiu mzdu dosahujú zamestnanci so základným vzdelaním, a to $\mathrm{v}$ priemere $510 €$. Z hl'adiska veku mzda s rastúcim vekom rástla a vrchol dosiahla u zamestnancov vo veku od 30 do 34 rokov a to $801 €$. Potom s d'alším rastom veku mala priemerná mzda klesajúce hodnoty. Preto môžeme konštatovat', že v Žilinskom kraji mali za rok 2010 najvyššiu priemernú mesačnú mzdu zamestnanci s vysokoškolským vzdelaním 3. stupňa vo veku od 30 do 34 rokov. [11]

\section{Ciel' výskumu}

Pred začatím výskumu sme si stanovili hlavný ciel' práce: analyzovat' priemerné hrubé mzdy zamestnancov medzi jednotlivými krajmi Slovenska a porovnat' mzdy zamestnancov podl'a veku, pohlavia a dosiahnutého vzdelania. Porovnávali sme mesačné mzdy zamestnancov, ktorí sa dostali do výberového súboru, ktorý bol náhodným reprezentatívnym súborom, medzi jednotlivými krajmi podl’a priemerov. Zamerali sme sa tiež špeciálne na mzdy zamestnancov v Poštových službách a v Telekomunikáciách. Potom sme porovnávali jednotlivé kraje s celoslovenským priemerom podl'a zvoleného kritéria veku, pohlavia a dosiahnutého vzdelania. V tomto príspevku popíšeme zistené výsledky výskumu o priemerných mesačných mzdách obyvatel’ov Žilinského kraja. Stanovili sme si nasledujúce hypotézy. [13]

Hypotéza A1. Vek zamestnancov Žilinského kraja vplýva na ich priemerné hrubé mesačné mzdy.

Vzhl'adom na to, že skúmané údaje nespínajú predpoklad o normalite rozdelenia, použili sme neparametrickú obdobu jednofaktorovej analýzy rozptylu pre nezávislé výbery, ktorou je Kruskal - Wallisov test. Pomocou neho sme zist'ovali, či stredné hodnoty miezd závisia alebo nezávisia od veku. Za účelom testovania sme si stanovili nasledujúce hypotézy:

$\mathrm{H}_{0}$ : Neexistuje rozdiel medzi strednými hodnotami miezd zamestnancov podl'a vekových kategórií. Stredné hodnoty miezd teda nezávisia od veku zamestnancov.

$\mathrm{H}_{1}$ : Existuje rozdiel medzi strednými hodnotami miezd zamestnancov podl'a vekových kategórií. Stredné hodnoty miezd teda závisia od veku zamestnancov. 
Hypotéza A2. Existuje štatisticky významný rozdiel ${ }^{1}$ medzi výškou mzdy zamestnancov $v$ Žilinskom kraji a celoslovenskou priemernou mzdou zamestnancov rozdelených do vekových kategórií.

Pre porovnanie priemerných mesačných miezd s celoslovenským priemerom podl'a vekových kategórií sme si zadefinovali nasledujúce hypotézy, ktoré sme následne testovali t-testom takto:

$\mathrm{H}_{0}$ : Priemerné hrubé mesačné mzdy zamestnancov Žilinského kraja podl’a vekových kategórií sa rovnajú priemerným hrubým mesačným mzdám Slovenska podl'a vekových kategórií.

$\mathrm{H}_{1}$ : Priemerné hrubé mesačné mzdy zamestnancov Žilinského kraja podl'a vekových kategórií sa nerovnajú priemerným hrubým mesačným mzdám Slovenska podl'a vekových kategórií.

Hypotéza B1. Stupeň dosiahnutého vzdelania zamestnancov Žilinského kraja vplýva na ich priemerné hrubé mesačné mzdy.

Pomocou už spomínanej neparametrickej obdoby analýzy rozptylu sme zist'ovali, či stredné hodnoty miezd závisia alebo nezávisia od dosiahnutého vzdelania. Za účelom testovania sme si stanovili nasledujúce hypotézy:

$\mathrm{H}_{0}$ : Neexistuje rozdiel medzi strednými hodnotami miezd zamestnancov podl'a stupňa dosiahnutého vzdelania. Stredné hodnoty miezd teda nezávisia od vzdelania zamestnancov.

$\mathrm{H}_{1}$ : Existuje rozdiel medzi strednými hodnotami miezd zamestnancov podl'a stupňa dosiahnutého vzdelania. Stredné hodnoty miezd teda závisia od vzdelania zamestnancov.

Hypotéza B2. Existuje štatisticky významný rozdiel medzi výškou mzdy zamestnancov $v$ Žilinskom kraji a celoslovenskou priemernou mzdou zamestnancov rozdelených do kategórií podl'a stup̌̆a ich vzdelania.

Pre porovnanie priemerných mesačných miezd s celoslovenským priemerom podla dosiahnutého stupňa vzdelania sme si zadefinovali hypotézy, ktoré sme následne testovali takto:

$\mathrm{H}_{0}$ : Priemerné hrubé mesačné mzdy zamestnancov Žilinského kraja podl'a stupňa ich dosiahnutého vzdelania sa rovnajú priemerným hrubým mesačným mzdám Slovenska podl’a dosiahnutého stupňa vzdelania.

$\mathrm{H}_{1}$ : Priemerné hrubé mesačné mzdy zamestnancov Žilinského kraja podl'a stupňa ich dosiahnutého vzdelania sa nerovnajú priemerným hrubým mesačným mzdám Slovenska podl'a dosiahnutého stupňa vzdelania.

Hypotéza C1. Priemerné hrubé mesačné mzdy zamestnancov v Žilinskom kraji sú závislé od pohlavia.

Pomocou Kruskal - Wallisovho testu sme zist'ovali, či stredné hodnoty miezd závisia alebo nezávisia od pohlavia. Za účelom testovania sme si stanovili nasledujúce hypotézy:

$\mathrm{H}_{0}$ : Neexistuje rozdiel medzi strednými hodnotami miezd zamestnancov podla pohlavia. Stredné hodnoty miezd teda nezávisia od pohlavia zamestnancov.

\footnotetext{
1 Za štatisticky významný budeme považovat' taký rozdiel, ktorý bude overený pomocou testu štatistickej hypotézy na zvolenej hladine významnosti $\alpha=0,05$.
} 
$\mathrm{H}_{1}$ : Existuje rozdiel medzi strednými hodnotami miezd zamestnancov podl'a pohlavia. Stredné hodnoty miezd teda závisia od pohlavia zamestnancov.

Hypotéza C2. Existuje štatisticky významný rozdiel medzi výškou mzdy zamestnancov $v$ Žilinskom kraji a celoslovenskou priemernou mzdou zamestnancov rozdelených do kategórií podl'a pohlavia.

$\mathrm{H}_{0}$ : Priemerné hrubé mesačné mzdy zamestnancov Žilinského kraja podl'a pohlavia sa rovnajú priemerným hrubým mesačným mzdám Slovenska podl'a pohlavia.

$\mathrm{H}_{1}$ : Priemerné hrubé mesačné mzdy zamestnancov Žilinského kraja podl'a pohlavia sa nerovnajú priemerným hrubým mesačným mzdám Slovenska podl’a pohlavia.

\subsection{Metódy výskumu a výskumná vzorka}

Pre náš výskum sme použili $1 \%$ náhodného výberu zo štatistického súboru zistených miezd v rámci Slovenskej Republiky od súkromnej spoločnosti Trexima, spol. s.r.o. Pri analýze miezd zamestnancov sme použili matematicko - štatistické metódy spracovania údajov, metódu indukcie, dedukcie a komparácie. Výskumná vzorka pozostáva z $1 \%$ náhodného výberu zamestnancov v rámci Slovenskej Republiky. Obsahuje údaje o mzdách, pohlaví, vzdelaní odvetví a kraji, v ktorom zamestnanci pracujú. Celkový počet respondentov bol 9900 . Z toho v Žilinskom kraji bolo 1126 respondentov, z nich v oblasti Poštových služieb a Telekomunikácií sa do vzorky dostalo 16 zamestnancov. [10]

\section{Výsledky výskumu}

Z poskytnutých údajov $1 \%$ náhodného výberu od spoločnosti Trexima, s.r.o., nám priemerná celoslovenská hrubá mzda vyšla $829 €$, čo je v porovnaní s priemernou celoslovenskou hrubou mzdou, udávanou Štatistickým úradom Slovenskej republiky, o $3 €$ menej. Priemerná hrubá mzda zamestnancov v Žilinskom kraji bola pre túto vzorku $763 €$. Priemerná hrubá mesačná mzda zamestnancov voblastiach Poštových služieb a Telekomunikácií bola $730 €$.

Uvedieme výsledky zo štatistického testovania hypotéz, ktoré sme si stanovili v predchádzajúcej časti.

Hypotéza A1: Výška priemernej mesačnej mzdy zamestnancov Žilinského kraja závisí od veku zamestnancov.

Ako už bolo spomenuté vyššie, túto hypotézu sme overovali pomocou Kruskal - Wallisovho testu, ktorý je neparametrickou alternatívou analýzy rozptylu pre nezávislé náhodné výbery. Výsledky testu udáva nasledujúca tabul'ka.

Tabul'ka 2: Kruskal - Wallisov test závislosti mzdy zamestnancov v Žilinskom kraji od veku

\begin{tabular}{lr|rr}
\multicolumn{2}{c}{ Kruskal-Wallis Test } & \multicolumn{2}{c}{ Kruskal-Wallis Test } \\
Chi-Square & 43.8252 & Chi-Square & 3.0662 \\
DF & 9 & DF & 6 \\
Pr $>$ Chi-Square & $<.0001$ & Pr $>$ Chi-Square & 0.8005
\end{tabular}

Zdroj: vlastné spracovanie údajov od spoločnosti Trexima, s.r.o. 
Tabul'ka vl'avo je pre všetkých zamestnancov v Žilinskom kraji, tabul'ka vpravo je pre zamestnancov Žilinského kraja v oblasti Poštových služieb a v oblasti Telekomunikácií.

$\mathrm{Na}$ základe $\mathrm{p}$ - hodnoty testu, ktorá je výrazne menšia, ako zvolená hladina významnosti, zamietame nulovú hypotézu, to znamená, že existuje štatisticky významný rozdiel medzi strednými hodnotami miezd zamestnancov podla vekových kategórií. Prijímame hypotézu $\mathrm{H}_{1}$, teda stredné hodnoty miezd zamestnancov v regióne Žilina závisia od veku zamestnancov.

Ak zúžime výberovú vzorku len na zamestnancov Poštových služieb a Telekomunikácií, na základe $\mathrm{p}$ - hodnoty tohto testu nulovú hypotézu nezamietame. To znamená, že stredné hodnoty miezd zamestnancov v týchto dvoch sférach nezávisia od veku zamestnancov.

Hypotéza A2: Výška priemernej mesačnej mzdy zamestnancov jednotlivých vekových kategórií v Žilinskom kraji je rovnaká, ako priemerná celoslovenská mzda.

Túto hypotézu sme overovali pomocou t - testu. Hodnota testovacej štatistiky je $-2,73$, kritická hodnota $\mathrm{t}$ - rozdelenia s 9 stupňami vol'nosti je 2,26. Ked’že platí nerovnost' $|-2,73| \geq 2,26$, na hladine významnosti 0,05 zamietame nulovú hypotézu. To znamená, že stredné hodnoty hrubej mesačnej mzdy zamestnancov jednotlivých vekových kategórií v Žilinskom kraji sa líšia od celoslovenského priemeru.

Hypotéza B1: Výška priemernej mesačnej mzdy zamestnancov v Žilinskom kraji je ovplyvnená stupňom ich dosiahnutého vzdelania.

Výsledky testu sú v nasledujúcej tabul'ke.

Tabul'ka 3: Kruskal - Wallisov test závislosti mzdy zamestnancov v Žilinskom kraji od vzdelania

\begin{tabular}{cr}
\multicolumn{2}{c}{ Kruskal-Wallis Test } \\
Chi-Square & 234.6454 \\
DF & 10 \\
Pr $>$ Chi-Square & $<.0001$
\end{tabular}

\begin{tabular}{lr}
\multicolumn{2}{|c}{ Kruskal-Wallis Test } \\
Chi-Square & 9.5735 \\
DF & 4 \\
Pr $>$ Chi-Square & 0.0483
\end{tabular}

Zdroj: vlastné spracovanie údajov od spoločnosti Trexima, s.r.o.

Tabul'ka vl'avo je testom pre všetkých zamestnancov v Žilinskom kraji, druhá tabul'ka je pre zamestnancov v oblasti Poštových služieb a Telekomunikácií.

Obidve p - hodnoty testu sú v porovnaní so zvolenou hladinou významnosti menšie, teda zamietame nulovú hypotézu. To znamená, že existuje štatisticky významný rozdiel medzi strednými hodnotami miezd zamestnancov podl'a stupňa dosiahnutého vzdelania. Prijímame hypotézu $\mathrm{H}_{1}$, teda stredné hodnoty miezd zamestnancov v regióne Žilina závisia od vzdelania a to isté platí aj pre mzdy zamestnancov Žilinského kraja v oblasti Poštových služieb a Telekomunikácí́.

Hypotéza B2: Výška priemernej mesačnej mzdy zamestnancov, rozdelených podl'a stupňa ich vzdelania, je v Žilinskom kraji rovnaká, ako priemerná celoslovenská mzda.

Hodnota testovacej štatistiky obojstranného $\mathrm{t}$ - testu je $-1,70$, kritická hodnota $\mathrm{t}$ - rozdelenia s 10 stupňami vol'nosti je 2,23. Ked’že nerovnost' $|-1,70| \geq 2,23$ neplatí, na hladine významnosti 0,05 nezamietame nulovú hypotézu. To znamená, že stredné hodnoty hrubej mesačnej mzdy zamestnancov podl'a vzdelanostných stupňov v Žilinskom kraji sa nelíšia od celoslovenského priemeru. 
Hypotéza C1: Priemerné mesačnej mzdy zamestnancov v Žilinskom kraji sú závislé od pohlavia.

Výsledky testu sú v nasledujúcej tabul'ke.

Tabul'ka 4: Kruskal - Wallisov test závislosti mzdy zamestnancov v Žilinskom kraji od pohlavia

\begin{tabular}{|c|c|}
\hline \multicolumn{2}{|c|}{ Kruskal-Wallis Test } \\
Chi-Square & 121.1614 \\
DF & 1 \\
\hline Pr $>$ Chi-Square & $<.0001$ \\
\hline
\end{tabular}

\begin{tabular}{l|r|}
\multicolumn{2}{|c|}{ Kruskal-Wallis Test } \\
\hline Chi-Square & 3.8054 \\
\hline DF & 1 \\
\hline Pr $>$ Chi-Square & 0.0511 \\
\hline
\end{tabular}

Zdroj: vlastné spracovanie údajov od spoločnosti Trexima, s.r.o.

P - hodnota testu pre všetkých zamestnancov v Žilinskom kraji je ovel'a menšia, ako zvolená hladina významnosti 0,05 , zamietame teda nulovú hypotézu, že neexistuje štatisticky významný rozdiel medzi strednými hodnotami miezd zamestnancov podl'a ich pohlavia. Prijímame hypotézu $\mathrm{H}_{1}$, teda stredné hodnoty miezd zamestnancov v regióne Žilina závisia od pohlavia.

P - hodnota testu pre zúžený výber zamestnancov v Žilinskom kraji v oblasti Poštových služieb a v oblasti Telekomunikácií je o málo väčšia ako zvolená hladina významnosti $\alpha=0,05$, teda $\mathrm{v}$ tomto prípade nezamietneme nulovú hypotézu. To znamená, že stredné hodnoty miezd zamestnancov v regióne Žilina v sfére Poštových služieb a Telekomunikácií nezávisia od pohlavia zamestnancov.

Hypotéza C2: Výška priemernej mesačnej mzdy zamestnancov, rozdelených do skupín podl’a pohlavia, je v Žilinskom kraji rovnaká, ako priemerná celoslovenská mzda.

Hodnota testovacej štatistiky obojstranného $\mathrm{t}$ - testu je -10,39, kritická hodnota $\mathrm{t}$ - rozdelenia s 1 stupňami vol'nosti je 12,71 . Ked’že nerovnost' $|-10,39| \geq 12,71$ neplatí, na hladine významnosti 0,05 nezamietame nulovú hypotézu. To znamená, že stredné hodnoty hrubej mesačnej mzdy zamestnancov podl'a pohlavia v Žilinskom kraji sa nelíšia od celoslovenského priemeru.

\section{Záver}

Ako sme zistili vyššie, vek zamestnanca ovplyvňuje výšku jeho hrubej mesačnej mzdy. Diferenciácia miezd zamestnancov podl'a veku je spôsobená viacerými dôvodmi. Pri mladých zamestnancoch priemerné mzdy sú nižšie, pretože mladí l'udia ešte nemajú pracovnú prax a skúsenosti. Mzdy však postupne s pribúdajúcim vekom majú rastúci charakter. Starší zamestnanci, napriek slušnej zbierke skúseností, si hl'adajú prácu t’ažšie. Zamestnávatelia sa obávajú, že starší l'udia sú menej flexibilní a produktívni, majú problémy zvládnut' nové trendy. Preto aj mzdy od určitého veku už majú klesajúcu tendenciu. Navyše sme zistili, že v Žilinskom kraji majú zamestnanci, kategorizovaní podl'a veku, významne odlišné priemerné mzdy v porovnaní s celoslovenským priemerom.

Z celkovej analýzy, týkajúcej sa vplyvu vzdelania na výšku mzdy vyplýva, že je potrebné sa vzdelávat'. Zamestnanci s vysokoškolským vzdelaním dosahujú vyššie mzdy ako zamestnanci s nižším vzdelaním. Podl'a nášho zistenia nie je významný rozdiel medzi mzdami zamestnancov Žilinského kraja a celoslovenskými mzdami zamestnancov, kategorizovaných podl'a stupňa vzdelania.

$\mathrm{Z}$ náhodného reprezentatívneho súboru miezd zamestnancov, ktorý sme mali $\mathrm{k}$ dispozícii tiež môžeme vidiet', že stále pretrvávajú mzdové rozdiely medzi pohlaviami. Muži zvyknú 
pracovat' $\mathrm{v}$ iných odvetviach hospodárstva ako ženy. Odvetvia, financované štátom, ako polícia a armáda, ktoré môžeme označit' ako typické mužské odvetvia, sú lepšie platené ako školstvo a zdravotníctvo, kde hlavne na nižších pozíciách pracujú najmä ženy. Ďalším z dôvodov, prečo majú ženy nižšie mzdy ako muži, je prerušenie kariéry kvôli materstvu a rodičovstvu. Preto je pre ženy t'ažšie stúpat' po kariérnom rebríku až na vyššie posty v manažmente a dosahovat' tak vyššie mzdy.

\section{Literatúra}

[1] Horváthová, M. : Mzdová problematika od 1.1.2011, Košice, 2011, ISBN 978-80969572-5-5

[2] Ochotnícky, P. Autner, R.: Základné makroekonomické proporcie vývoja ekonomiky Slovenska v roku 2010, Bratislava, 2010, ISBN 978-80-89105-40-3

[3] Jurga, R. : Kvantitatívna makroekonómia, EKONÓM, 2005, ISBN 80-225-2080-2

[4] Vokorokosová, R. : Minimálna mzda a konkurencieschopnost', Košice, 2008, ISBN 97880-8086-093-6

[5] Sojka, L.: Regionálny rozvoj v kontexte vzdelanostných faktorov, Prešov, 2006, ISBN 808068-574-6

[6] Štatistický úrad Slovenskej republiky : Regióny Slovenska, Bratislava, 2004, ISBN 80224-0817-4

[7] Rimarčík, M. : Štatistika pre prax, Košice, 2007, ISBN 978-80-969813-1-1

[8] Belajová, A. Fáziková, M. : Regionálna ekonomika. Nitra, 2005, ISBN 80-8069-513-X

[9] Kachaňáková, A. : Riadenie l’udských zdrojov. Bratislava, 2003, ISBN 80-89085-2-2-9

[10] Trexima. [online]. [citované 2012-04-15]. Dostupné na internete: http://www.trexima.sk/new/

[11] Štatistický úrad Slovenskej republiky. [online]. [citované 2012-04-15]. Dostupné na internete : http://portal.statistics.sk/showdoc.do?docid=1477

[12]Regióny. [online]. [citované 2012-04-15]. Dostupné na internete: http://regiony.szm.com/kraje.htm

[13] SMIEŠKOVÁ, M.: Diferenciácia miezd zamestnancov $\mathrm{v}$ regiónoch Slovenska: diplomová práca. Bratislava: Univerzita Komenského v Bratislave, Fakulta managementu, 2012. 